\title{
From Plowing to Penitence Piers Plowman and Fourteenth-Century Theology
}

\author{
By Denise N. Baker
}

Perhaps no episode in medieval literature has proven as puzzling to modern readers as the pardon scene in the $\mathrm{B}$ text of Piers Plowman.* Critics continue to debate whether the document which Piers receives in Passus VII is a pardon. The document is, after all, sent by Truth, the divine authority whose tower overshadows the fair field. Its message - "Et qui bona egerunt ibunt in vitam eternam; / Qui vero mala in ignem eternum" - is an article of the Athanasian Creed and thus an orthodox tenet of the faith. Moreover, critics who argue that Truth's document is a pardon maintain that its text is consistent with the theme of the Visio. Frank, for example, contends that "the message of the pardon, do well, is a logical culmination of the doctrine of labor and good works preached throughout the Visio. If the pardon is no pardon, if do well is not the way to salvation, the reader has been led down the garden path by a most irresponsible poet." Many readers of Piers Plowman remain uncomfortable with this interpretation, however, because, contrary to what we expect, Piers himself tears up the parchment from Truth and vows to change his life. Piers's response is hardly that of a man who accepts "do wel and haue wel" as a pardon, and his action forces us to examine what doing well meant to a medieval audience. If we place the poem in a historical context, we discover the importance of a crucial theological controversy of the fourteenth century to the understanding of the issues involved in the pardon scene. The relationship between the "doctrine of labor and good works" expressed in Truth's pardon and in the theological debate between the Augustinians and the Nominalists demonstrates conclusively that Langland does not intend Truth's pardon as a true pardon. ${ }^{2}$

Let us begin by considering the circumstances in which Piers receives the

* A research grant for the summer of 1978 from the University of North Carolina at Greensboro enabled me to complete this essay. An earlier version of it was presented at the Fourth Annual Meeting of the Southeastern Medieval Association held at the University of Kentucky on March 3-4, 1978.

${ }^{1}$ Robert W. Frank, Jr., Piers Plowman and the Scheme of Salvation (New Haven, 1957), p. 25.

${ }^{2}$ Two other critics who consider the influence of fourteenth-century theology on the pardon scene of Piers Plowman are John Francis McNamara, "Responses to Ockhamist Theology in the Poetry of the Pearl-poet, Langland, and Chaucer" (Ph.D. diss., Louisiana State University, 1968), pp. 89-96, and Elizabeth Kirk, The Dream Thought of Piers Plowman (New Haven, 1972), pp. 97-99. Both McNamara and Kirk argue, however, that Truth's message to Piers is a pardon. 
message from Truth in the B text. The plowman first appears on the fair field in Passus V, after the confession of the Seven Deadly Sins. He immediately assumes the role of a guide in directing the penitents on a pilgrimage to Truth. According to Piers the repenting sinners can approach Truth's castle by obeying the Mosaic Law, but they can gain entrance only through penance and grace. ${ }^{3}$ Before the pilgrimage can proceed, however, Piers decides to plow his half acre and, at the beginning of Passus VI, he engages the penitents to assist him in this task. The day's work soon extends to a half year and the temporary postponement becomes permanent. Piers never embarks on the pilgrimage, but in Passus VII he nonetheless receives a pardon.

An important consideration in evaluating the document which Piers receives in Passus VII, then, is whether he attains the goal of the pilgrimage, that is, the pardon, without undertaking the actual journey. Since Piers's directions to Truth's castle are allegorical and the path he describes leads inward to Truth in man's heart, we might assume, as Burrow does, that Langland does not distinguish between pilgrimage and plowing and that the plowing of the half acre is, indeed, the pilgrimage. ${ }^{4}$ In the last of his four references to the pilgrimage in Passus VI, Piers himself equates the journey to Truth with plowing.

"I wol worshipe perwip trupe by my lyue,

And ben his pilgrym atte plow for pouere mennes sake."

(6.101-2)

Furthermore, in Passus VII Truth seems to affirm Piers's identification of plowing as pilgrimage by sending him the pardon.

Treupe herde telle herof, and to Piers sente

To [t]aken his teme and tilien pe erpe,

And purchaced hym a pardoun a pena $\Xi$ a culpa

For hym and for hise heires eueremoore after.

And bad hym holde hym at home and erien hise leyes,

And alle pat holpen to erye or to sowe,

Or any [maner] mestier bat my3te Piers [helpe],

Pardon wip Piers Plowman trupe hap ygraunted.

From this evidence Burrow concludes that "Piers and his faithful followers ... are on the highway to Truth, 'non pedibus, sed moribus,' when they stay at home labouring in their vocations and helping their neighbours, since this is

\footnotetext{
${ }^{3}$ Piers Plowman: The B Version, ed. George Kane and E. Talbot Donaldson (London, 1975), 5.560-608. All subsequent quotations are from this edition.

${ }^{4}$ John Burrow, "The Action of Langland's Second Vision," Essays in Criticism 15 (1965), 247-68. Mary Carruthers agrees with Burrow's conflation of plowing and pilgrimage in The Search for St. Truth (Evanston, 1973), pp. 64-66.
} 
the way of truth which Truth himself taught. They are worshipping him not in Jerusalem but in spirit - 'by their lives' as Piers says (VI, 103)."

Although Burrow's explanation seems reasonable, it does not adequately explain Langland's rejection of plowing as pilgrimage in the pardon scene. After Piers tears up the document from Truth, he explicitly reverses the decision he made in Passus VI.

... "Si ambulauero in medio vmbre mortis

Non timebo mala quoniam tu mecum es.

I shal cessen of my sowyng," quod Piers, "\& swynke nozt so harde,

Ne aboute my [bilyue] so bisy be na moore;

Of preieres and of penaunce my plouz shal ben herafter,

And wepen whan I sholde [werche] bouz whete breed me faille."

Not only does Piers destroy the document, he also ignores Truth's command to cultivate his land. Instead of forsaking the pilgrimage to plow his half acre, Piers will, in the future, direct his energies toward acts of atonement. Piers's reaction thus refutes Burrow's claim that Langland equates plowing with pilgrimage; obviously, the poet distinguishes between these two activities and our understanding of the meaning of this distinction is crucial to our understanding of the pardon scene. ${ }^{6}$ How must the message from Truth be interpreted, then, to account for Piers's change from plowman to pilgrim?

Although the message of Truth's pardon, which Frank paraphrases as "do good works and be saved," poses no difficulty for the modern reader, the issue was much more complex and controversial for Langland's original audience. Conflicting views about man's ability to do good works were at the heart of a theological dispute waged throughout the fourteenth century between the Augustinians and the Nominalists. ${ }^{7}$ The Augustinians regarded

${ }^{5}$ Burrow, "Action," p. 259.

${ }^{6}$ In Piers Plowman: An Interpretation of the A-Text (Dublin, 1937), T. P. Dunning also discusses this distinction between plowing and pilgrimage, but he argues that plowing exemplifies man's means of providing himself with the bona temporalia necessary to maintain life and that this issue is Langland's primary concern in the Visio (pp. 127-31 and 147-52).

${ }^{7} \mathrm{My}$ discussion focuses on only one of the many issues addressed by fourteenth-century scholasticism. For an assessment of recent scholarship on the various schools of fourteenthcentury thought and a survey of Ockhamist views on epistemology, ethics, and society, see William J. Courtenay, "Nominalism and Late Medieval Religion," in The Pursuit of Holiness in Late Medieval and Renaissance Religion, ed. Charles Trinkaus with Heiko Oberman (Leiden, 1974), pp. 26-59. As Courtenay indicates, historians now recognize three movements of late scholasticism: a conservative Augustinian group (including Thomas Bradwardine and Gregory of Rimini); a moderate or Ockhamist group (including Ockham, Pierre d'Ailly, and Gabriel Biel); and a radical group (including Robert Holcot, Adam Woodham, Nicholas of Autrecourt, and John of Mirecourt). Despite several differences between them, the moderate and radical groups share a semi-Pelagian concept of salvation and a contractual model of the relationship between God and man (pp. 47, 51). Following the suggestion of Courtenay, I will use Nominalist to refer to these similarities between the moderates and the radicals (p. 53). In my discussion of fourteenth-century theology, I am also indebted to the following scholars: Gordon Leff, Bradwardine and the Pelagians (Cambridge, Eng., 1957); idem, Gregory of Rimini (Manchester, Eng., 
the Nominalist position as Pelagian; in his De causa Dei Bradwardine attacked those of his contemporaries who "cum Pelagio pro libera arbitrio contra gratuitam tuam pugnant." 8 While the two groups disagreed on several theological matters, including the causes of predestination and justification, the most important point of contention for our purposes involved the relationship between grace and good works.

The Augustinians, of course, claimed that man did not have the natural ability to perform good works and that his will had been further debilitated by original and personal sin. Therefore, grace was necessary to enable man to do good. By insisting on man's need for such prevenient grace, however, the traditional Augustinians did not deny free will. Rather, they argued that without grace man's will was not free but paralyzed by sin. Prevenient grace emancipated man's will from the shackles of sin and allowed him to choose between good and evil. If, as a result of this emancipation of the will, man chose to do good, grace also enabled him to accomplish the good work. Augustine distinguished these two effects of prevenient grace as operation and cooperation.

Et quis istam etsi parvam dare coeperat charitatem, nisi ille qui praeparat voluntatem, et cooperando perficit, quod operando incipit? Quoniam ipse ut velimus operatur incipiens, qui volentibus cooperatur perficiens. . . . Ut ergo velimus, sine nobis operatur; cum autem volumus, et sic volumus ut faciamus, nobiscum cooperatur: tamen sine illo vel operante ut velimus, vel cooperante cum volumus, ad bona pietatis opera nihil valemus. ${ }^{9}$

Through this distinction between the two stages of prevenient grace, operation and cooperation, the Augustinians simultaneously affirmed man's dependence on grace and the freedom of his will. In the first stage, the operation of grace instilled faith in man; if he then desired to do good, he

1961), pp. 155-242; idem, William of Ockham (Manchester, Eng., 1975), pp. 470-525; Heiko Oberman, "Some Notes on the Theology of Nominalism," Harvard Theological Review 53 (1960), 47-76; idem, The Harvest of Medieval Theology (Cambridge, Mass., 1963); idem, ed., Forerunners of the Reformation, trans. Paul L. Nyhus (New York, 1966), pp. 123-64; David Knowles, The End of the Middle Ages, vol. 2 of The Religious Orders in England (Cambridge, Eng., 1955), pp. 74-89.

${ }^{8}$ Quoted from De causa Dei by James A. Weisheipl, "Ockham and Some Mertonians," Mediaeval Studies 30 (1968), 193. Although Bradwardine was an important critic of the Nominalists, his concept of divine participation in every human act was not in keeping with traditional Augustinianism. I do not contend that Langland was influenced by either Bradwardine or his disciple, Wyclif. Rather, Langland's view is similar to that of traditional Augustinians like Gregory of Rimini. For a discussion of the differences between Bradwardine and Gregory, see Leff, Gregory, pp. 239-42. Although Oberman identifies Gregory of Rimini as a "right wing nominalist," he uses this term to designate the conservative Augustinian group of fourteenthcentury scholasticism and acknowledges that Gregory is "one of the most impressive representatives of late medieval Augustinianism" (Harvest, p. 204, and "Some Notes," pp. 51-56; Courtenay, "Nominalism," p. 34).

9 Augustine, De gratia et libero arbitrio 17.33, PL 44:901. I quote Augustine rather than one of his fourteenth-century disciples because their works are not available in modern editions, but see Leff, Gregory, pp. 180-81. 


\section{Piers Plowman and Fourteenth-Century Theology}

would pray for the cooperation of grace to accomplish the act. As Augustine wrote:

Ergo spiritus gratiae facit ut habeamus fidem, ut per fidem impetremus orando, ut possimus facere quae jubemur. Ideo ipse Apostolus assidue legi praeponit fidem: quoniam quod lex jubet, facere non valemus, nisi per fidem rogando impetremus, ut facere valeamus. ${ }^{10}$

Faith, then, was evidence that prevenient grace was operating in man and prayer, proof that man desired to cooperate with grace. And, according to the Augustinians, grace preceded both free will and good works.

While the Augustinians emphasized the priority of grace, the Nominalists insisted that man was sufficiently free to dispose himself to receive God's grace. ${ }^{11}$ Thus the Nominalists contradicted the Augustinian teaching about man's debilitated nature. Despite original sin, they claimed man's will was free and it need not be emancipated by prevenient grace before he could do good. Ockham, for example, asserted that man, relying solely on his natural ability, can love God above all else. ${ }^{12}$ Furthermore, the Nominalists contended that through good works accomplished ex puris naturalibus man gained grace and merit de congruo. ${ }^{13}$ Although they acknowledged that this merit derived not from the intrinsic value of man's natural acts, but from God's decision under his potentia ordinata to accept these acts as meritorious, the Nominalists nevertheless argued that God must grant grace and merit $d e$ congruo to the man who facit quod in se est. They fostered a contractual model of the relationship between man and God and "often interpreted the covenant of salvation in the sense that God was a debtor, committed to reward

10 Augustine, De gratia 14.28, PL 44:898.

${ }^{11}$ The Nominalists emphasized the distinction between God's potentia absoluta, the omnipotence which made all things possible to him except contradiction, and his potentia ordinata, the limitations which God placed on his omnipotence in establishing the present order. In their speculations about God's potentia absoluta, the Nominalists contended that the habit of grace was not necessary for salvation; Ockham, for example, argued, "Nihil est meritorium nisi quod est in nostra potestate, ergo actus non est meritorious principaliter propter illam gratiam, sed propter voluntatem libere causantem, ergo posset Deus talem actum elicitum a voluntate acceptare sine gratia" (Quodlibetum 6, q. 1, quoted by Knowles, End, p. 79). Ockham's view about the irrelevance of grace under the potentia absoluta was censured as Pelagian at Oxford and Avignon in the 1320s. Although the Nominalists conceded that grace was necessary for salvation under God's potentia ordinata or the established order, they continued to insist on the semiPelagian idea that free will and not grace was the primary cause of good acts. See Courtenay, “Nominalism," pp. 37-43 and 47; Oberman, Harvest, pp. 139-41, 176-77, 246, and 427.

${ }^{12}$ Leff, William, p. 493, and Oberman, Harvest, pp. 210-11.

${ }^{13}$ Medieval theologians distinguished between two kinds of merit, de condigno and de congruo. Man gained merit de condigno, or strict merit, only by performing good works in a state of habitual grace. According to the Nominalists, however, man could also acquire merit de congruo for good works performed without habitual grace. The Augustinians denounced this emphasis on merit de congruo as Pelagian. See Leff, Bradwardine, pp. 156-59 and 203-05, Gregory, pp. 177 and 180, William, pp. 493-95; Oberman, Forerunners, pp. 129-33. 
with grace and eventually with eternal life the man who did what was in him." 14

The Nominalists thus reversed the Augustinian teaching: grace was not the prerequisite but the consequence of good works. Their contractual attitude contrasted sharply with the Augustinian view that man received grace "not ex pacto but ex misericordia Dei," not as payment but as gift. ${ }^{15}$ Moreover, the Augustinians rejected the notion of merit de congruo, insisting instead that only good works performed by a man in the state of habitual grace earned merit de condigno. In the fourteenth century, then, the Nominalist semi-Pelagian view that free will and not grace was the primary cause of good works contradicted the traditional Augustinian emphasis on man's dependence on God's mercy and grace.

If we consider Langland's Visio in the context of this important fourteenth-century debate, we recognize that plowing and pilgrimage indicate the contending opinions about good works and grace expressed by the Nominalists and the Augustinians. Plowing represents the Nominalist view that man can earn grace through good works; that he can, without any special help from God, "do wel and haue wel." ${ }^{16}$ Pilgrimage, on the other hand, is a penitential act through which man acknowledges his need for grace in order to accomplish good works; it thus represents the Augustinian view. ${ }^{17}$ If we examine Piers's reaction to the document from Truth, we recognize the dominance of Augustinian theology in Langland's poem. At the moment of tearing the pardon, Piers is a man in whom God's grace is

${ }^{14}$ William J. Courtenay, “Covenant and Causality in Pierre D'Ailly,” Speculum 46 (1971), 118 , and "Nominalism," p. 51.

${ }^{15}$ Courtenay, “Covenant," p. 100; Augustine, De gratia 5.11, PL 44:888.

${ }^{16}$ In his discussion of Chaucer's Plowman, Donald Howard comments: "And plowing itself symbolized the good works a Christian might do; the frequent references in Scripture to plowing and sowing were so interpreted, as the references to reaping and harvesting were understood to signify judgment" (The Idea of The Canterbury Tales [Berkeley, 1976], p. 101). Piers's plowing becomes allegorical in Dobest, but Langland explains the allegory to us. In the $V$ isio Langland uses literal plowing as an example of good works in general. See David Aers, Piers Plowman and Christian Allegory (New York, 1975), for a refutation of the allegorical interpretation of plowing in the Visio given by D. W. Robertson, Jr., and Bernard Huppé, Piers Plowman and Scriptural Tradition (Princeton, 1951).

${ }^{17}$ Critics of The Canterbury Tales have often discussed the penitential nature of pilgrimage. See Ralph Baldwin, The Unity of The Canterbury Tales, Anglistica 5 (Copenhagen, 1955), excerpts repr. in Chaucer Criticism: The Canterbury Tales, ed. Richard Schoeck and Jerome Taylor (Notre Dame, Indiana, 1960); and Charles P. R. Tisdale, "The Medieval Pilgrimage and Its Use in The Canterbury Tales" (Ph.D. diss., Princeton University, 1969). Frank, Scheme, pp. 30-33, argues that penance is the "do wel" referred to in Truth's document. However, this interpretation overlooks the fact that Truth's message also includes the command to continue plowing, a command which Piers explicitly violates in turning to the penitential life. In this context, then, "do wel" must refer to works such as plowing rather than to penance. Later in the poem Conscience and Patience redefine dowel as penance and faith (14.16-28, 14.82-97). Piers's conversion in Passus VII anticipates this penitential definition in Passus XIV, but we misinterpret the poem if we violate its sequence of ideas. 
operating. His response begins with a declaration of faith: " 'Si ambulauero in medio vmbre mortis / Non timebo mala quoniam tu mecum es' " (7.12021). Then he realizes the foolishness and futility of trying to perform good works without God's help; the plowing which he believed was a good act he now sees was wrongly motivated.

"I shal cessen of my sowyng," quod Piers, "\& swynke nozt so harde, $\mathrm{Ne}$ aboute my [bilyue] so bisy be na moore"

Finally, Piers vows to seek the strength he requires to do good works from God. " 'Of preieres and of penaunce my plouz shal ben herafter'" (7.124). In turning from plowing to pilgrimage Piers is following an Augustinian injunction: "ut homo qui voluerit et non potuerit, nondum se plene velle cognoscat, et oret ut habeat tantam voluntatem, quanta sufficit ad implenda mandata. Sic quippe adjuvatur, ut faciat quod jubetur." ${ }^{18}$ Piers's change from plowman to penitent is a repudiation of the Nominalist claim that man can do good without grace. His affirmation of faith indicates that grace is operating in him; his vow to pray and do acts of penance demonstrates that he is cooperating with grace.

The pardon scene is thus the moment of Piers's conversion. Prior to this episode, Piers himself exhibits a confidence in his own ability to do good works and earn grace which reveals a Nominalist tendency. When he first appears in the poem, he describes his relationship with God as that of employee to employer.

"I haue ben his folwere al pis [fourty] wynter,

Bope ysowen his seed and suwed hise beestes,

WibInne and wibouten waited his profit,

Idyke[d] and Id[o]lue, Ido bat [he] hotep.

Som tyme I sowe and som tyme I presshe,

In taillours craft and tynkeris craft, what trupe kan deuyse,

I weue and I wynde and do what trube hotep.

For bouz I seye it myself I serue hym to paye;

I haue myn hire [of hym] wel and ouperwhiles moore.

$\mathrm{He}$ is be presteste paiere pat pouere men knoweb;

He wiphalt noon hewe his hire bat he ne hap it at euen."

(5.542-52)

In this passage Piers boasts of his ability to do as Truth bids, to serve him satisfactorily; he makes no mention of man's need for prevenient grace. And in the directions to Truth's castle which Piers gives the penitents, he claims that grace follows rather than precedes good works (5.561-608). Furthermore, the wage metaphor that Piers uses to describe his relationship with God indicates that he believes his good works deserve repayment according 
to the rule of measurable hire (3.255-258), that grace is a recompense for services rendered rather than a generous gift from God. ${ }^{19}$

It is precisely this contractual attitude which informs the Nominalist discussion of merit de congruo and Truth's pardon:

". . . do wel and haue wel, and god shal haue pi soule,

And do yuel and haue yuel, [and] hope bow noon ooper

[That] after pi deeb day pe deuel shal haue pi soule."

In the pardon scene, however, Piers comes to realize his mistake. ${ }^{20} \mathrm{He}$ has learned through his failure on the half acre that natural man is unable to do well; he even finds himself guilty of being too concerned about his bely ioye. Piers's "pure tene" is therefore directed against himself, for he recognizes that he has been a fool. In tearing up the document from Truth, he acknowledges that he cannot earn grace and salvation through his own works. ${ }^{21}$ Piers thus repudiates the semi-Pelagianism of Nominalism and assumes an Augustinian posture with his expression of faith and his vow of penance, hoping that a merciful God will give him the grace to accomplish the good works he cannot perform naturally.

One major objection to this interpretation of Piers's response is that the

19 Piers's view resembles the Pearl Dreamer's interpretation of the parable of the laborers in the vineyard. The Pearl maiden corrects this attitude, explaining that even the best of men sin and must be saved by God's mercy and grace, not their own works. See Pearl, ed. E. V. Gordon (Oxford, 1953), §§ 9-12, pp. 18-26; Kirk, Dream Thought, p. 77.

${ }^{20}$ Kirk, Dream Thought, pp. 77, 88-93, and Carruthers, Search, pp. 72-75, discuss Piers's conversion in Passus VII as a change from an Old to a New Law psychology. However, as Courtenay observes, there is a striking similarity between the Hebrews' attitude toward their covenant with Yahweh and the Nominalists' interpretation of their relationship with God under his potentia ordinata ("Covenant," p. 118). Since Piers's allegorical map to Truth in Passus V includes not only the Ten Commandments but also grace and the sacrament of penance, it is more appropriate to identify it with the semi-Pelagian Nominalist concept of merit de congruo than with the Old Law alone.

${ }^{21}$ Most critics believe that Piers is angry with the priest for denying that Truth's message is a pardon. Robertson and Huppé, Scriptural Tradition, pp. 93-94, Frank, Scheme, pp. 28-29, and Carruthers, Search, p. 77, all argue that Piers tears up the document in order to contrast his true understanding of its meaning with the literal-minded misinterpretation of the priest. However, this reading does not adequately account for Piers's failure to obey Truth's command to continue plowing. While Piers does argue with the priest for deriding his allusions to Scripture later in the scene, his conversion from plowing to penance indicates that he agrees with the priest, although perhaps for different reasons, that Truth's message is not a pardon. Kirk, Dream Thought, contends that Piers is outraged at Truth and that the plowman "vents his resentment at God's transcendent superiority on God's immanent manifestation of himself (the pardon) by destroying the manifestation, thereby releasing its energies" (p. 94). But Kirk's discussion of the pardon scene as an "explosive confrontation" (p. 95) between God's will and man's imposes a modern psychology on the poem. In Augustinian thought it is precisely an intervention by God, the infusion of grace, which frees man's will from the bondage of original sin. I cannot agree with Kirk's view that the pardon scene expresses "the ambivalence in man's attitude to salvation, which he resists as much as he desires it" (p. 96). 
document he tears up comes from Truth. It is obvious that Langland associates Truth with good works, for he sends Piers the pardon with the command to continue plowing. Why would Langland ascribe such a position to Truth? To answer this question we need only recognize that Truth is God the Father, the lawgiver and judge; his message to Piers is an injunction to obey the Law. The criterion for salvation established by Truth's document is valid, but it is impossible to fulfill without grace. Augustine, quoting Paul, emphasized man's inadequacy before the Law:

\begin{abstract}
"Quia non justificabitur ex lege omnis caro coram illo: per legem enim cognitio peccati" [Rom. 3.20] " "Cognitio" dixit; non, Consumptio. Quando autem cognoscit homo peccatum, si non adjuvat gratia ut cognitum caveatur, sine dubio lex iram operatur. . . non quia lex mala est; sed quia sub illa sunt quos reos facit jubendo, non adjuvando. Gratia quippe adjuvat ut legis quisque sit factor, sine qua gratia sub lege positus tantummodo erit legis auditor. ${ }^{22}$
\end{abstract}

Without grace, man stands condemned under the Law. By destroying the document from Truth, Piers admits his own inability to satisfy the demands of the Law and to accept such an injunction as a pardon. ${ }^{23}$ In rejecting Truth's message as a pardon, however, Piers does not repudiate the Law nor deny man's need to do well; rather he refutes the mistaken view that man can meet the conditions set by Truth through his own efforts. The Dreamer's conclusions about the superiority of dowel over purchased pardons at the end of the Visio are thus off the mark, for the real issue in the pardon scene is not whether man should do good works but how he can accomplish them.

Since Truth's "pardon" is an affirmation of Law and justice, it is not a true pardon. However, Piers's reading of it coincides with the infusion of preve-

${ }^{22}$ Augustine, De gratia 10.22, PL 44:894, and 12.24, PL 44:896. Kirk, Dream Thought, pp. 88-100, discusses Paul's Epistle to the Romans, from which Augustine quotes, as a commentary on the pardon scene. Although she presents a fine summary of Paul's concept of justification by faith rather than Law, she considers Truth's message as, paradoxically, a "pardon [couched] in words which are a formulation of the law" (p. 93). Kirk concludes that Truth's injunction to "do wel" is a pardon because she believes that Langland regards grace and salvation as the reward (meed) rather than the wages (measurable hire) for good works (p. 84, 93). Therefore, she argues that the pardon scene resolves the conflict between Nominalist and Augustinian theology because it asserts "that ethics both do and do not play a role in salvation" (p. 98). Despite her references to Paul and the fourteenth-century Augustinians, however, Kirk does not question man's ability to do well nor does she discuss grace as a prerequisite for good works. Thus she actually interprets Langland's pardon scene as an endorsement of the semi-Pelagian theology of Nominalism.

${ }^{23}$ Several critics associate Piers's tearing of the pardon with biblical and iconographic acts of destruction which mark the change from the Old to the New Law; see John Lawlor, "Piers Plowman: The Pardon Reconsidered," Modern Language Review 45 (1950), 456; Rosemary Woolf, "The Tearing of the Pardon," in Piers Plowman: Critical Approaches, ed. S. S. Hussey (London, 1969), pp. 70-75; and Carruthers, Search, p. 71. Although Lawlor and Woolf agree that Truth's message is a statement of Law and thus not a pardon, Carruthers contends that it is "a pardon . . . based on the Law" (p. 69). 
nient grace into his soul and, insofar as this confrontation with the Law incites Piers's awareness of his own inadequacy, it precipitates his cooperation with grace. Thus, while the Law itself is not grace, it often acts as a call to grace. As Augustine observed:

. . verum etiam quod visorum suasionibus agit Deus, ut velimus, et ut credamus, sive extrinsecus per evangelicas exhortationes, ubi et mandata legis aliquid agunt, si ad hoc admonent hominem infirmitatis suae, ut ad gratiam justificantem credendo confugiat; sive intrinsecus, ubi nemo habet in potestate quid ei veniat in mentem, sed consentire vel dissentire propriae voluntatis est. ${ }^{24}$

Although the words of Truth's document are not words of pardon, they are the occasion of Piers's conversion from a Nominalist theology of works to an Augustinian theology of grace.

But if Truth's document is not a pardon, why is it so identified in the poem? Is Truth guilty of untruth? Not at all. As Rosemary Woolf observes, "the true conclusion is not that Truth has lied, but that the poet for his own purposes has misled us; [for] it is the poet in his own voice, not God as a character in the poem who describes the document as a pardon." 25 Langland's deliberate deception of his audience in Passus VII is the culmination of the strategy he uses in the Visio to bring his readers to an Augustinian awareness of their own inadequacy. Through the discrepancy between what they expect from a pardon and what Piers receives from Truth, the poet hopes to shock his audience into a recognition of the Nominalist sophistry and thus demonstrate to them their own fallibility. ${ }^{26}$ Langland begins misleading his readers in Passus V when he encourages them to see Piers as the one exemplary man on the fair field. Although Piers's attempt to fulfill Truth's commands is more admirable than the palmer's ignorance of them, he, too, is in error because he does not acknowledge his need for prevenient grace. However, Langland does not immediately reveal the deficiency of Piers's attitude but rather allows his readers to believe that Piers's choice of plowing over pilgrimage is one which the poet endorses. Langland's silence

\footnotetext{
${ }^{24}$ Augustine, De spiritu et littera 34.60, PL 44:240. While Robertson and Huppé, Scriptural Tradition, pp. 91-94, and Carruthers, Search, pp. 69-70, recognize that man needs grace to perform good works, they contend that in giving Piers a command to obey the Law, Truth also gives him the grace to fulfill it. They conclude, therefore, that although Truth's message is literally an injunction to do good works, it is allegorically a pardon. But this interpretation violates Augustine's distinction between Law and grace and fails to explain Piers's conversion to the penitential life. Although Piers receives Truth's message at the same time he receives prevenient grace, the Law is not thus transformed into a pardon.

${ }^{25}$ Woolf, "Tearing," p. 53; but she explains the purpose of the deception as "poetic anticipation and illuminating paradox," arguing that although Truth's document is not a pardon when Piers receives it, it becomes one after he tears it up (p. 70).

${ }^{26}$ Woolf, "Tearing," pp. 53-54, and Kirk, Dream Thought, pp. 83-85, 98, also describe the reader's shock and bewilderment at Truth's message, but they attribute this effect to paradox rather than to Langland's strategy for converting his reader.
} 
thus induces his audience to share the plowman's confidence that man can do well ex puris naturalibus. Although the failure of Piers's efforts to reform the half acre calls into question such an optimism, the readers nonetheless believe that Piers deserves a reward because he facit quod in se est. The audience finds nothing amiss, then, when the narrator announces at the beginning of Passus VII that Truth has sent Piers a pardon even though he has not embarked on the pilgrimage. But Langland dramatically shatters his audience's expectations by making Truth's pardon a statement of Law and thus a startling indictment of the Nominalist view which Piers expresses. By asserting that natural man can obey the Law, the Nominalists were denying the effects of original sin, contending that Law itself was a "pardon" a pena et a culpa. But ironically if man could fulfill the conditions of such a "pardon," he would need no pardon at all. Confronted with the obvious discrepancy between the words of Truth's document and the claim that it is a pardon, Piers is forced to repudiate his previous Nominalist position. The reader, shocked and bewildered by Piers's response, also comes to a realization of his own fallibility.

Although Truth's pardon is not a true pardon, Langland is not, as Frank suggests, an irresponsible poet. ${ }^{27} \mathrm{He}$ leads his readers "down the garden path," encouraging them to make Nominalist assumptions about the relationship between good works and grace, as part of a sophisticated strategy designed to convert his audience to an Augustinian consciousness of man's dependence on God's gift of grace. At the end of the Visio, Langland exhorts his reader:

Forbi I counseille alle cristene to crie god mercy, And Marie his moder be meene bitwene, That god gyue vs grace er we go hennes Swiche werkes to werche, while we ben here, That, after oure deep day, dowel reherce A be day of dome we dide as he hizte.

Langland thus paradoxically misleads his readers in order to lead them to the truth.

\section{University of North Carolina, Greensboro}

\footnotetext{
${ }^{27}$ Lest any readers fail to perceive the inappropriateness of regarding Truth's message as a pardon, Langland presents three other documents later in Piers Plowman which correct the Visio's "pardon": the acquittance which Patience gives Haukyn in Dowel (14.180-95), the patent which Love sends to Peace in Dobet (18.182-87), and the pardon which Christ grants to Piers in Dobest (19.183-90). Thus in the Vita Langland explains discursively the ideas presented dramatically in the pardon scene and his temporary deception of his audience is not merely an irresponsible trick, but a strategy which provides the impetus for the rest of the poem.
} 